\title{
A comparative Study of the Liability of the Income Statement and the Liability of the Balance Sheet
}

\author{
Wang Jianbing ", Wang Jun
}

Huaiyin institute of technology, School of economics and management, Huaian 223001

wjb020412@163.com

Keywords: temporary differences, time difference, the balance sheet debt method, income statement debt method

\begin{abstract}
On February 15, 2006, the ministry of finance issued new enterprise accounting standards system, including the accounting standards for enterprises - income tax , which has clearly shown that we should apply the international balance sheet debt method to tax accounting. The view of assets and liability, as the theoretical basis of balance sheet debt method, pays more attention to the reality of transaction and event, so that it can make financial statements more true and fair.
\end{abstract}

\section{Introduction}

The income tax accounting standard is directly from the thought of international accounting standards - income tax. It introduces the concept of tax base and temporary differences .It requires that companies should adopt balance sheet debt method which is based on the view of assets and liability, and abandon the tax payable method and tax effect accounting method which is based on the profit view. Balance sheet debt method is based on the origination of temporary difference to analyze the causes of temporary differences and its influence to the final assets, liabilities, and recognizes it as deferred income tax liability or deferred income tax assets. While the income statement debt method recognizes the timeliness effect on future income tax as deferred tax. The maturity of the balance sheet debt method in theory makes it has more advantages in practice.

\section{The Connection and Difference between Temporary Difference and Time Difference}

\subsection{The Link between Temporary Differences and Temporal Differences}

Accounting income can be measured by the ratio of income and expense, and can be measured by the perspective of net assets. In general, if the confirmation of the tax law and accounting ,a revenue or expense at different times, it is bound to produce a different time and make a (or several) assets or liabilities' book value of the tax base have difference, which produce a temporary differences. Because the temporary difference and time difference is temporary, with the passage of time temporarily difference and time difference will switch back in the reversal period, when all reverse temporary difference and time difference is disappear, do not persist, in some cases, if time difference cannot be reversed or not completely reversed, then corresponding temporary differences are not reversed or not completely reversed.

2.2 The Difference between Temporary and Temporal Differences

a)The Different Concepts of the Two

Time difference refers to the tax law and accounting in confirmation of income and expenses at 
different time, tax accounting profit and taxable amount of income is different, this analysis method can only tell the time difference, and for other temporary differences ,it will be mistaken for permanent difference. Temporary difference refers to the book value and the tax basis of the assets and liabilities of difference is different, this analysis method can distinguish including time difference,other temporary differences and all temporary differences. From the concept of the category, the temporary differences are widely than the time differences, because the time difference must be temporary differences, and temporary differences are not necessarily a time difference.

b)The Focus of the Two Different

Time difference focus on income statement, profit from the table item of income or expense angle differences between accounting profits and taxable profits analysis, reflect a certain accounting period of such differences. Temporary difference focus on the balance sheet, it is from balance table angle of the assets and liabilities of the project analysis's difference between accounting profit and taxable income, revealing a point on the existence of such differences. From the perspective of accounting, the two elements of revenue and expense are dynamic elements, and the two elements of assets and liabilities are the elements of the static, and are the real elements. Income statement liability method is "movement" of the position with study of the income tax, because the revenues and expenses are the "flow" indicators; balance sheet liability method is to use "static" position and to investigate the income tax, because assets and liabilities are the stock index.

c)The Theoretical Basis of the Two Different

Time difference, emphasizing differences in the formation as well as the reversal and the effects of the income tax expense, but cannot directly reflect the impact of future, income statement debt method of vision on the "past and present", so its theoretical basis is the typical "profit apparent". Temporarily difference stressed differences in content and the ending balance of the effect, can directly obtain deferred income tax assets, deferred income tax liabilities balance, it can directly reflect the influence of the future, balance sheet debt method of eyes on "now and in the future", is a typical "asset liability view" because of the theoretical basis.

\section{The Necessity of the Balance Sheet Liability Method in the Substitution of the Income Statement Liability Method}

3.1 The Conceptual Categories of Temporary Differences Were more Complete than the Time Differences

In order to integrate with the international accounting practice, the enterprise accounting standards - income tax has been abandoned the concept of "time difference", and has been introduced the temporary difference. Range from temporary differences and timing differences of view, all the timing differences are temporary differences. Temporary differences not only it contains all timing differences, but also all of the other temporary timing differences are not difference, the amount of such differences is not so much, but it involves the large amount and cannot be neglected. It focuses on dealing with the disclosure of the temporary difference. it can be fully and completely reflected the payment of corporate income tax accounting process, to provide more comprehensive information on income tax accounting.

\subsection{The Balance Sheet Liability Method Can Improve the Quality of Accounting Information}

The apparent of balance sheet as the theoretical foundation for the balance sheet liability method, So the impact on the corporate income tax temporary differences are recognized in the balance sheet as "deferred tax assets" or "deferred tax liabilities" in the balance sheet.temporary 
differences is the balance between The carrying value of assets and liabilities and its tax base the impact of the tax, as reflected in "Deferred tax assets" or "deferred tax liabilities" has become an important corporate assets and liabilities and the book value constitution, which can fully reveal the asset or liability at the balance sheet date in future periods due to temporary differences lead to the cash inflow or outflow to help information users according to financial reports for the financial position and future cash flows to make appropriate evaluation and forecasting.

\section{The Impact on the Enterprise of Change of the Income Statement Debt Method to the Balance Sheet Liability Method}

\subsection{Impact on Enterprise Financial Statements Constitute Items}

The Enterprise Accounting Standards - income tax requires companies to lists deferred income tax assets and deferred income tax liabilities which come from temporary differences between the book value of the assets, liabilities and the tax base as non-current assets and non-current liabilities in the balance sheet respectively.at the same time,enterprises should check the book value of the deferred income tax assets based on the requirements of caution. If enterprises can't obtain sufficient taxable income in the future to offset the benefit of the deferred income tax assets and deferred income tax assets, they will write down the book value of the deferred income tax assets. Therefore, deferred income tax assets and deferred income tax liabilities produced by the balance sheet debt method have important influences on the composition of the financial statements of the enterprise .

\subsection{It Reduces the Fluctuations of After-Tax Profit}

Implementing tax rules can reflect the ratio of the income tax expenses shown in income statement and the current accounting profit more reasonably,thereby reducing the fluctuations of after-tax profit because the caliber between the tax law and accounting regulations is different.The balance sheet debt method recognizes assets and liabilities confirmed in balance sheet as the tax basis,and confirm influences of income tax due to temporary differences between accounting rules and tax law.In this way, It reduce the fluctuations of after-tax profit due to caliber inconsistent between accounting and tax law .

4.3 It Limit the Choice of the Income tax Accounting Method, Contain the Enterprise Profit Operation Space

The Enterprise Accounting Standards - income tax abandons the enterprises to adopt taxes payable method, income statement debt method and other methods.It requires using the balance sheet debt method for income tax accounting treatment,and confirm the result of the temporary differences of deferred income tax assets or the deferred income tax liabilities. When tax rate changes, enterprises should adjust the influence of the income tax due to the temporary differences between book value of assets, liabilities and different tax basis. Therefore, the implementation of the Enterprise Accounting Standards - income tax can match the income tax expenses shown in the income statement with the current accounting profit,which contain the enterprise profit operation space from a certain sense. 


\section{The Application of the Balance Sheet Debt Method}

5.1 Strengthen the Concept of Income Tax Accounting and Strengthen the Construction of Management System

The evaluation index is a kind of practical guidance. The transformation from profit outlook to balance sheet outlook asked that the original profit evaluation index change to enterprise capital management ability and other indicators, and it requires countries and enterprises and even the whole society should have a quick change in the concept, government performance evaluation system and construction of enterprise internal control process and management system should adapt to this change, so as to ensure the tax and income and other financial information can be correctly reflect and measure.

5.2 Strengthen the Training of Financial Personnel and Improve the Quality of Accounting Information

The balance sheet liability method requires that accounting personnel in enterprise must have fundamental reconsideration on accounting theory and practice, which requires that the accounting personnel must have higher professional ability and professional quality. Therefore, the enterprise must strengthen the training of professional financial personnel, to let them deeply study and grasp the essence of the balance sheet liability method, to improve accounting personnel's ability to understand and use the balance sheet liability method, and to improve the quality of accounting information.

\section{References}

[1] LuFuxia, WangJiaqing. A study of accounting for income tax with the liability method in the balance sheet. World of Entrepeneurs, 2013(11): 101-102

[2] WangJianbing. The philosophic thought from the liability method of the balance sheet. The friend of accounting, 2006(10): 20-21

[3] HuangTaohong. The accounting of the balance sheet with the liability method in the balance sheet. The accounting of township enterprises in China, 2013(11): 57-58

[4] LiWei,HaoWenxia.The discussion about timing differences with the liability method in the balance sheet.The monthly periodical of accounting,2008(06):10

[5] XiongZhen,ZhangJian.Analysis of timing differences and temporary differences.Taxation and accounting,2006(01): 69-71 